J. Perinat. Med. 15 (1987) 263

\section{Constancy of serum angiotensin-converting enzyme activity in normal and complicated pregnancy}

\author{
Michael J. Gast ${ }^{1}$, Lee A. Rigg1, Cheryl L. Amyx ${ }^{2}$, and Gerald Kessler ${ }^{2}$ \\ ${ }^{1}$ Department of Obstetrics and Gynecology, Washington University School of \\ Medicine, St. Louis, Missouri, and ${ }^{2}$ Department of Pathology and Laboratory \\ Medicine, Division of Biochemistry, Jewish Hospital of St. Louis, Missouri, \\ U.S.A.
}

\section{Introduction}

Although serum levels of angiotension II appear to remain relatively constant during pregnancy, the pregnant woman's ability to respond to infusion of the pressor substance is markedly diminished [1]. It is hypothesized that angiotensin converting enzyme (ACE), either through it's direct actions or it's inhibitory effect upon bracykinin, could play an important role in the development of the hypertensive disorders of pregnancy.

The precise role of ACE in the process is uncertain. Limited data are available about the rate of conversion of angiotensin I to angiotensin II or the catabolism of this decapeptide in the pregnant patient. Because vascular endothelial cells are believed to be the major site of synthesis for ACE, the marked increase in vascularity of the uterus during pregnancy would be expected to lead to increased levels of serum activity of the enzyme. Diabetes and hyperthyroidism have also been associated with elevations of serum angiotensin converting enzyme (SACE) activity $[6,10]$. Similar changes in glucose/insulin and thyroid hormone dynamics that occur in the normal pregnant woman thus might also contribute to changes in SACE activity during gestation.

\section{Curriculum vitae}

Michael J. GaST was born 1948 in Milwaukee, Wisconsin. He graduated Magna cum laude from the University of Illinois, Urbana, Illinois. He studied medicine at the Ohio State University, graduating in 1973; and received his Ph.D. in Molecular Biology from Washington University, St. Louis in 1981.

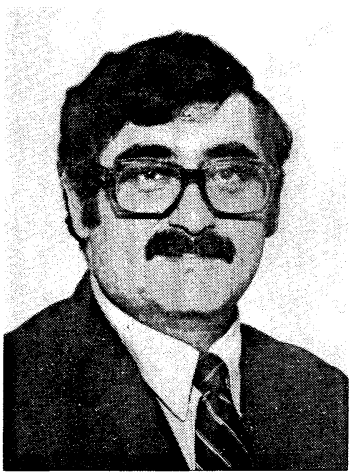
After completing his residency in Obstetrics and Gynecology at Washington University School of Medicine in 1976, he completed a fellowship in Maternal-Fetal Medicine in 1981, and a second fellowship in Endocrinology/Infertility in 1985. He is presently an Assistant Professor of Obstetrics and Gynecology at Washington University School of Medicine.

PARENTE, et al. [8] measured SACE activity in 52 normal pregnant women at various stages of gestation. They concluded that levels during pregnancy did not change, and were consistent with those of normal non-pregnant controls. OATs, et al. [7] prospectively evaluated multiple samples for SACE activity in 18 normal primigravidae and concluded that enzyme activity was depressed during normal pregnancy, but rose as pregnancy advanced into the third tri- 
mester, and returned to non-pregnant levels by 6 weeks postpartum. RASMUSSEN, et al. [9] found that normotensive pregnant subjects studied during pregnancy and 5 days post-partum had lower SACE activity compared to their own levels 3 to 6 months following delivery or to a group of non-pregnant control women.

We prospectively evaluated SACE activity in pregnant women with hypertensive disorders and diabetes in order to evaluate the test's ability to predict pregnancy induced hypertension and to understand it's role in the reninangiotensin system's dynamics. Pregnancy creates a unique environment for studying the dynamics of the renin-angiotensin system because of characteristic marked and abrupt changes in blood pressure, intravascular volume and angiotensin sensitivity. We elected to study SACE activity during the major vascular volume changes that occur in the first trimester of pregnancy, the relative vascular stability of the second and early third trimesters, the period of modest vascular constriction just prior to term, and the marked vascular readjustments of the postpartum period. Evaluation of SACE activity at 6 weeks postpartum was used as a baseline for the non-pregnant state and compared to the various gestational periods.

\section{Materials and methods}

Patients were drawn from Washington University prenatal clinics, and from the private prac- tices of members of the full-time staff of the Department of Obstetrics and Gynecology. All patients were between the ages of 18 and 35 and gave full informed consent for participation. They were screened to exclude Sarcoidosis, Gaucher's disease, hyperthyroidism, and other disorders (with the exception of hypertension and diabetes) in which active disease may be marked by an elevation of SACE activity. The duration of pregnancy was established either by ultrasonic cephalometry or by excellent clinical dating, including a known last menstrual period, consistent first examination, early pregnancy test, and fetal heart tones at 20 weeks of gestation. The delivery dates were established by review of each patients' hospital records. Patients classified as diabetic had either a long history of type I diabetes with insulin therapy or were gestational diabetics with abnormal glucose tolerance testing in the first trimester. Chronic hypertensive patients all had elevated blood pressures (systolic greater than $130 \mathrm{~mm} \mathrm{Hg}$; diastolic greater than $90 \mathrm{~mm}$ $\mathrm{Hg}$ ) prior to pregnancy and off medications. All were under therapy with at least one antihypertensive agent during the study, but none were treated with any agent that was classified as an ACE inhibitor.

Blood samples were collected from pregnant patients at the specific stages of pregnancy outlined in table I. The serum was separated and immediately frozen prior to evaluation of ACE activity. All specimens were assayed within 2 weeks of collection and storage.

Table I. Blood samples collected from pregnant women.

\begin{tabular}{|c|c|c|c|c|c|c|}
\hline \multirow{2}{*}{$\begin{array}{l}\text { Weeks of } \\
\text { gestation }\end{array}$} & \multicolumn{6}{|c|}{ Number of samples drawn } \\
\hline & Normal & $\mathrm{PIH}$ & $\begin{array}{l}\text { Chronic } \\
\text { hypertensive }\end{array}$ & Diabetic & $\begin{array}{l}\text { Total } \\
\text { samples }\end{array}$ & $\begin{array}{l}\text { Total } \\
\text { patients }\end{array}$ \\
\hline $8-13$ weeks & 27 & 6 & 5 & 13 & 51 & 43 \\
\hline $14-26$ weeks & 46 & 4 & 10 & 21 & 81 & 58 \\
\hline $27-36$ weeks & 33 & 10 & 13 & 35 & 91 & 53 \\
\hline $37-40$ weeks & 15 & 2 & 3 & 6 & 26 & 24 \\
\hline 2 days postpartum & 3 & 5 & 0 & 5 & 13 & 9 \\
\hline 6 weeks postpartum & 16 & 6 & 5 & 13 & 40 & 40 \\
\hline Total & 144 & 33 & 36 & 93 & 306 & $112^{*}$ \\
\hline
\end{tabular}

* all patients were sampled at multiple times during gestation 
Enzyme activity was determined by the fluorometric assay technique of FRIEDLAND and SILVERSTEIN [1]. This procedure measures the dipeptide hydrolysis product histidyl-leucine generated by ACE activity on the substrate hippuryl-L-histidyl-L-leucine. The histidyl-leucine is reacted under alkaline conditions with o-pthaldialdehyde and the fluorophore quantitated fluorometrically after acidification. The normal range in our laboratory (established in a mixed population of men and non-pregnant women of higher average age than the pregnant patients in this study) is $44 \mathrm{nM} / \mathrm{min} / \mathrm{ml} \pm 12$ (1 S. D.). Mean values and standard deviations for each time interval during pregnancy and for the postpartum period were calculated and compared using the Student's t-test or Fischer's exact $t$-test for matched pairs.

\section{Results}

SACE activity demonstrates no significant alteration during the course of normal pregnancy, nor does it vary during pregnancies complicated by diabetes mellitus, chronic hypertension, or pregnancy-induced hypertension (PIH). Among the 112 patients studied, there were no significant differences of enzyme activity over any of the four time intervals studied (figure 1). The combined mean SACE activity seemed to rise modestly as gestation advanced, decreased markedly in the postpartum period and rose to levels above those of pregnancy at 6 weeks postpartum. SACE activity measured 6 weeks postpartum was significantly higher for both normal and complicated patients than enzyme activity measured during pregnancy $(P$ $<0.05)$. SACE activities drawn $1-3$ days postpartum appeared to be lower than those during pregnancy or in the late postpartum period $(\mathrm{P}$ $<0.05)$ for all samples, but the paucity of samples within the smaller subgroups drawn at this time period precluded a mean difference having statistical significance when patients were used as their own controls in evaluating the patients with various pregnancy complications.
SACE activity at all stages of pregnancy does not differ significantly when comparing patients with chronic hypertension or pregnancy-induced hypertension to those women

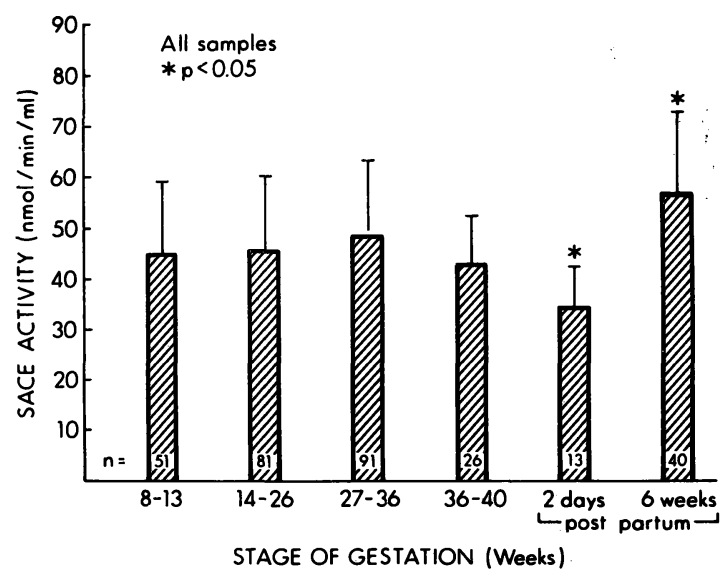

Figure 1. SACE activity during pregnancy. 112 women were prospectively surveyed for SACE activity at four gestational stages and postpartum. These women displayed significantly decreased levels of serum activity at two days postpartum and significantly higher SACE activity at six weeks postpartum when compared with all stages of pregnancy. Procedures for sample collection and processing are outlined under materials and methods. Results are expressed as mean \pm 1 standard deviation.

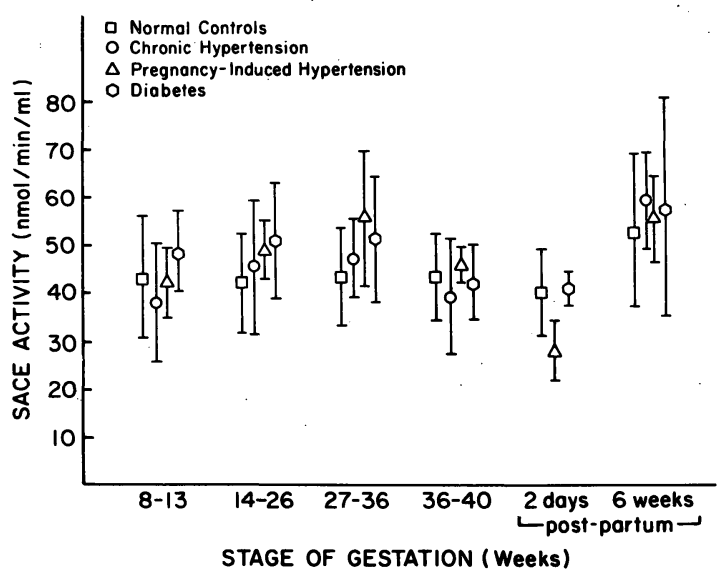

Figure 2. SACE activity was evaluated in pregnancies complicated by chronic or pregnancy-induced hypertension and in pregnancies complicated by diabetes mellitus. There was no significant difference in SACE activity between any of these groups and a population of control women at any stage of pregnancy or postpartum. Results are expressed as mean \pm 1 standard deviation. 


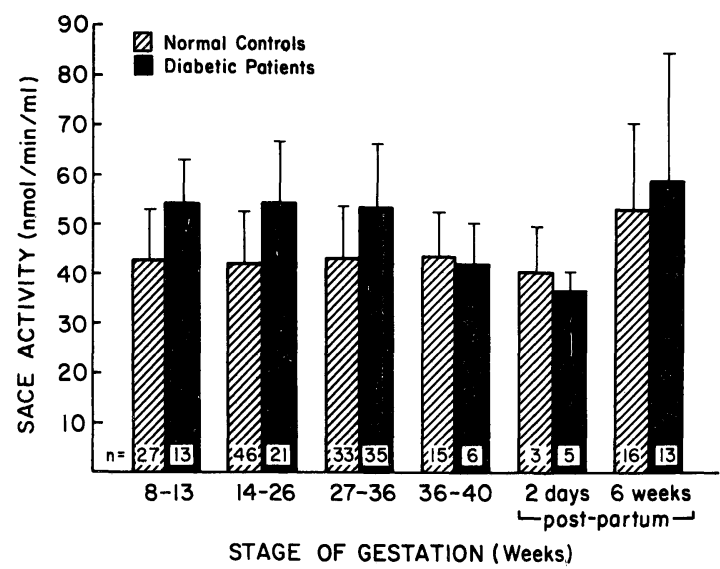

Figure 3. A comparison of SACE activity in pregnancies complicated by diabetes and normal pregnancies reveals a consistently elevated activity during most of gestation. This elevation was not significant, however, and could be accounted for by the markedly elevated values of a small subgroup of diabetic patients (see Results). Data are expressed as mean SACE activity level \pm 1 standard deviation.

with a normal pregnancy (figure 2). Pregnant diabetics as a group displayed higher mean SACE activity at most stages of gestation than the normal control population (figure 3) although these differences failed to reach statistical significance. The presence of microvascular disease was not a good predictor of elevated SACE activity among diabetic pregnant patients. Similarly, fetal macrosomia, White's classification, or insulin requirement did not predict those women with increased activity (table II).

\section{Discussion}

$\mathrm{ACE}$ is a $\mathrm{COOH}$-terminal peptidyl dipeptide hydrolase responsible for the physiological conversion of angiotensin-I to biologically active angiotensin II. Because of the central role of the renin-angiotensin system in hypertensive disorders of pregnancy, we evaluated SACE activity in 112 pregnant women in a prospective fashion. In a population of normal pregnant women, SACE levels decreased slightly from non-pregnant values and remained relatively stable throughout the remainder of gestation. The immediate postpartum period was accompanied by a decrease in SACE activity when compared to pregnant levels. SACE activity during pregnancy complicated by chronic hypertension or by pregnancy-induced hypertension was not different than the normal pregnant population.

Because diabetes has been suggested as a possible cause of elevations of SACE activity, we also prospectively surveyed a population of pregnant diabetic women. LIEBERMAN and SASTRE [6] studied a heterogeneous population of males and non-pregnant females with diabetes and were able to demonstrate an increase in mean enzyme activity compared to non-diabetic control subjects. They related this elevation to the presence of microvascular disease. SACE levels in the pregnant diabetic patients we studied were slightly higher than our normal population (figure 3) but demonstrated similar

Table II. Examination of the clinical characteristics of diabetic pregnant women in whom SACE activity is greater than two standard deviations above the mean for normal pregnancy fails to reveal a consistent pattern of macrosomia or small vessel disease. Classification of diabetes in pregnancy follows WHITE's criteria [11]. Normal values for hemoglobin $\mathrm{A} 1 \mathrm{C}$ in our laboratory are less than $8.5 \%$. N. D. signifies test not performed.

\begin{tabular}{llllll}
\hline $\begin{array}{l}\text { Case } \\
\text { No. }\end{array}$ & $\begin{array}{l}\text { Diabetic } \\
\text { classi- } \\
\text { fication }\end{array}$ & $\begin{array}{l}\text { Fetal } \\
\text { macro- } \\
\text { somia }\end{array}$ & $\begin{array}{l}\text { Average } \\
\text { Hgb A1C }\end{array}$ & $\begin{array}{l}\text { Average } \\
\text { SACE } \\
\text { activity }\end{array}$ & PIH \\
\hline 1 & A & No & 8.0 & 94 & No \\
2 & C & No & 8.3 & 69 & Yes \\
3 & C & No & 10.3 & 85 & No \\
4 & A & Yes & 6.4 & 62 & Yes \\
5 & C & Yes & 7.8 & 90 & No \\
6 & D & No & N.D. & 77 & No \\
7 & B & No & 7.7 & 62 & \\
\hline
\end{tabular}


trends during and following pregnancy. This rise in mean SACE levels could be accounted for almost entirely by a subpopulation of diabetic women whose SACE activity was consistently elevated to values greater than 2 standard deviations above the mean at all stages of gestation evaluated. Analysis of the nature of the diabetes and its complications seen in this group of women (table II) failed to reveal a factor or factors responsible for the rise in SACE activity when compared to the group of diabetic women with levels comparable to those in the normal population. It is possible that, as suggested by other authors [3], the elevation of SACE activity in these patients may be related to proliferation of non-vascular tissues and to generalized vasodilation.

The decrease in SACE activity in the $2-3$ days following pregnancy which we observed is consistent with decreases in other components of the renin-angiotensin system (plasma renin activity, angiotensin II, and aldosterone) in the immediate postpartum period [3]. We believe that the slight decrease in SACE activity in pregnancy when compared to the non-pregnant state and particularly the drop in enzyme activity during the first days postpartum, may represent an important step in the vasodilation of early pregnancy and the puerperium. Because $\mathrm{ACE}$ is known to catalyze the inactivation of the potent vasodilator bradykinin [4], it is possible that the removal of converting-enzyme inhibition of bradykinin activity may be linked in some regulatory fashion to a variety of physiologic vasodilatory processes that occur in the puerperium.

Our results suggest that SACE activity levels are unaffected by hypertension in the pregnant patient. This seems to be true regardless of the etiology of the blood pressure increase. LEE and TODD [5] measured SACE activity in ten women with positive supine pressor tests and seven normotensive controls. They found SACE activity in those patients with a positive rollover test to be significantly higher than in the normotensive group. Our results suggest that pregnancy-induced hypertension can be neither predicted nor diagnosed by measurement of SACE activity. We further conclude that although serum angiotensin-converting enzyme activity is somewhat responsive to pregnancy (including immediate postpartum events) it is unlikely that changes in this aspect of reninangiotensin dynamics play a causative role in the pathophysiology of either acute or chronic hypertensive processes during pregnancy.

\begin{abstract}
Angiotensin-converting enzyme occupies a central position in the dynamics of the renin-angiotensin system. We prospectively studied serum angiotensin-converting enzyme activity in 112 women at various stages of pregnancy and in the postpartum period because converting enzyme levels have not been well documented in pregnant women with medical disorders which might be expected to influence intravascular volume or blood
\end{abstract}

pressure. Enzyme activity is lower during pregnancy than it is in the same population at 6 weeks postpartum. Levels of serum angiotensin converting enzyme activity remain relatively stable during gestation but drop during the immediate postpartum period. Diabetes, chronic hypertension, and pregnancy induced hypertension fo not markedly change serum angiotensin converting enzyme activity.

Keywords: Diabetes and pregnancy, pregnancy-induced hypertension, serum angiotensin converting enzyme activity.

\section{Zusammenfassung}

Angiotensin-Converting-Enzym im Serum bei normaler and risikobehafteter Schwangerschaft

Im Renin-Angiotensin-System nimmt das AngiotensinConverting-Enzym (ACE) eine zentrale Position ein. In einer prospektiven Studie bestimmten wir bei 112 Frauen bei unterschiedlichem Gestationsalter sowie postpartal die Aktivität des Serum-Angiotensin-Converting-Enzyms (SACE). Bisher gibt es keine Spiegelbestimmungen 
bei schwangeren Frauen mit Krankheitsbildern, die möglicherweise das intravaskuläre Volumen oder den Blutdruck beeinflussen.

Über die genaue Funktion des ACE bei den komplexen, vaskulären Veränderungen in der Schwangerschaft gibt es nur unklare Vorstellungen. Das verfügbare Material über die Konversionsrate vom Angiotensin I zum Angiotensin II oder den Katabolismus dieses Dekapeptids bei schwangeren Frauen ist begrenzt. Man nimmt an, daß das vaskuläre Endothel der Hauptsyntheseort des ACE ist. So könnte man denken, daß die starke Vaskularisierung des. Uterus während der Schwangerschaft zu einer deutlichen Erhöhung der Serumaktivität dieses Enzyms führt. Bei Diabetes und bei der Hyperthyreose hat man auch Erhöhungen der SACE-Aktivität beobachtet [6, 10]. In der normalen Schwangerschaft treten vergleichbare Veränderungen bezüglich der Glukose/Insulin- und der Schilddrüsenhormonregulation auf, so $\mathrm{da} B$ auch unter diesem Aspekt eine Beeinflussung der SACE-Aktivität zu erwarten wäre.

Die Enzymaktivität wurde mit einer fluorometrischen Methode nach FRIEDLAND und SILVERSTEIN [1] bestimmt. Bei diesem Ansatz wird das Dipeptid Histidyl-Leucin erfaßt, das nach Hydrolyse des Substrats Hippuryl-LHistidyl-L-Leucin unter Mitwirkung des ACE entsteht. Weder bei normalen Schwangerschaftsverläufen noch bei Schwangerschaften mit chronischer Hypertonie oder schwangerschaftsinduzierter Hypertonie kam es zu signifikanten Veränderungen der SACE-Aktivität. Bei den 112 Patientinnen wurde die Enzymaktivität in 4 unterschiedlichen Zeitintervallen bestimmt, ohne daß signifikante Unterschiede auftraten. Während der Schwangerschaft ist die Enzymaktivität niedriger als in dem glei- chen Kollektiv 6 wochen post partum. Die Spiegel bleiben während der Schwangerschaft relativ konstant, sinken aber unmittelbar post partum. Die Werte, die 1-3 Tage post partum gemessen wurden, lagen niedriger als die während der Schwangerschaft oder in der späten Postpartalperiode. Bei Diabetes, chronischer Hypertonie oder schwangerschaftsinduzierter Hypertonie war die SACE-Aktivität nicht wesentlich verändert.

Im Vergleich zum Normalkollektiv waren die SACESpiegel bei schwangeren Diabetikerinnen geringfügig höher (Abb. 3), während und nach der Schwangerschaft zeigten sich aber die gleichen Trends wie oben beschrieben. Dieser geringfügige Anstieg mag aber auch damit zusammenhängen, da $B$ wir bei einer Untergruppe von Diabetikerinnen immer SACE-Aktivitäten gemessen haben, die um mehr als zwei Standardabweichungen höher lagen als die Mittelwerte aus allen von uns erfaßten Gestationsabschnitten. Bei genauerer Betrachtung dieser diabetischen Patientinnen bzw. ihrer Komplikationen (Tab. I) konnten wir jedoch im Vergleich zu Diabetikerinnen, die Werte wie das Normalkollektiv zeigten, keine Faktoren finden, die für den Anstieg der ACEAktivität verantwortlich zu machen wären.

Unsere Ergebnisse zeigen, daß mit der Messung der SACE-Aktivität eine schwangerschaftsinduzierte Hypertonie weder vorausgesagt noch diagnostiziert werden kann. Obwohl die SACE-Aktivität in der Schwangerschaft bzw. post partum gewisse Veränderungen zeigt, ist es unwahrscheinlich, daß im Hinblick auf das ReninAngiotensin-System diese Prozesse eine kausale Rolle bei der Pathophysiologie akuter oder chronischer Hypertonien während der Schwangerschaft spielen.

Schlüsselwörter: Angiotensin-Converting-Enzym-Aktivität im Serum, Diabetes und Schwangerschaft, schwangerschaftsinduzierte Hypertonie.

\section{Résumé}

Constance de l'activité sérique de l'enzyme de conversion de l'angiotensine au cours de la grossesse normale et de la grossesse compliquée

L'enzyme de conversion de l'angiotensine (A.C. E.) occupe une place centrale dans la dynamique du système rénine angiotensine. Nous avons étudié de façon prospective l'activité sérique de l'enzyme de conversion de l'angiotensine (S. A. C. E.) chez 112 femmes à différents stades de la grossesse et en post-partum, car, les taux de l'enzyme de conversion n'ont pas été étudiés chez la femme enceinte présentant une pathologie médicale dont on pourrait s'attendre qu'elle influence le volume intravasculaire ou la pression sanguine.

Le rôle précis de l'A.C. E. dans les modifications vasculaires complexes de la grossesse est incertain. On ne dispose que de données limitées sur le taux de conversion de l'angiotensine I en angiotensine II ou sur le catabolisme de ce décapeptide, chez la femme enceinte. Puisque l'on croit que les cellules de l'endothélium vasculaire représentent le site principal de synthèse de l'A.C.E., on devrait s'attendre à ce que l'augmentation importante de la vascularisation de l'utérus au cours de la grossesse entraîne une augmentation des taux d'activité sérique de cette enzyme. Le diabète et l'hyperthyroïdie s'accompagnent d'une élévation de l'activité S.A.C.E. [6, 10]. Les mêmes modifications, concernant glucose et insuline ainsi que que la dynamique des hormones thyroïdiennes, que celles qui surviennent au cours de la grossesse normale peuvent aussi contribuer à modifier l'activité S. A. G.E. pendant la grossesse.

L'activité enzymatique a été déterminée par la technique de dosage fluorométrique de FriedLand et SiLVERSTEIN [1]. Cette méthode mesure le dipeptide, produit d'hydrolyse, histidyl-leucine engendré par l'action de l'A.C.E. sur le substrat hippuryl-1-histidyl-1-leucine.

Il n'y a pas d'altération significative de l'activité S. A. C.E. au cours de la grossesse normale, ni de variations au cours des grossesses compliquées de diabète 
sucré, d'hypertension chronique, ou d'hypertension induite par la grossesse (P.I.H.). Chez les 112 patientes étudiées, il n'y a pas de différence significative de l'activité enzymatique et cela quel que soit l'un des intervalles de temps étudiés. L'activité enzymatique est plus basse pendant la grossesse qua'à 6 semaines de post-partum dans la même population. Les taux sériques d'activité de l'enzyme de conversion de l'angiotensine demeurent relativement stables pendant la grossesse mais chutent dans le post-partum immédiat. L'activité S. A.C.E. déterminée dans la à 3 jours post-partum est inférieure à celle de la grossesse ou de celle du post-partum tardif. Le diabète, l'hypertension chronique, et l'hypertension induite par la grossesse ne modifient pas de façon nette l'activité sérique de l'enzyme de conversion de l'angiotensine.

Les taux de S. A. C. E. chez les patientes diabétiques que nous avons étudiées sont légèrement plus élevés que ceux de notre population normale (Figure 3) mais ils suivent les mêmes évolutions au cours et après la grossesse. Cette élévation des taux moyens de S.A.C.E., peut être liée presque entièrement à une sous population de femmes diabétiques dont l'activité S. A.C.E. est nettement élevée au-dessus de la moyenne de 2 déviations standards quel que soit les stades du la grossesse, étudiés. L'analyse de la nature du diabète et de ses complications dans ce groupe de femmes (tableau I) ne permet pas de mettre en évidence un ou plusieurs facteurs responsables de l'élévation de l'activité S. A.C. E., lorsque on le compare au groupe de femmes diabétiques dont les taux sont comparables à ceux de la population normale.

Nos résultats suggèrent que l'hypertension induite par la grossesse ne peut être ni prédite, ni diagnostiquée par la mesure de l'activité S.A.C.E. Nous concluons également que bien que l'activité sérique de l'enzyme de conversion de l'angiotensine soit en quelque sorte sensible à la grossesse (en encluant le post-partum immédiat) il est improbable que les modifications du sytème rénineangiotensine à ce niveau jouent un rôle causal dans la physiopathologie de la maladie hypertensive de la grossesse qu'elle soit aigue ou chronique.

Mots-clés: Activité serique de l'enzyme de conversion de l'angiotensine, diabète et grossesse, hypertension induite par la grossesse.

\section{References}

[1] FrIEDland J, E Silverstein: A sensitive fluorometric assay for serum angiotensin-converting enzyme. Am J Clin Pathol 66 (1976) 4161

[2] Gant NF, GL Daley, S Chand, PJ Whalley, PC MCDonalD: A study of angiotensin II pressor response throughout primigravida pregnancy. J Clin Invest 52 (1973) 2682

[3] JADOUL FAC, FB PIPKIN, GD LAMming: Changes in the renin-angiotensin-aldosterone system in normotensive primigravidae in the four days after normal spontaneous delivery. Br J Obstet Gynaecol 89 (1982) 6336

[4] JoHNSON AR, EG ERDos: Metabolism of vasoactive peptides by human endothelial cells in culture. Angiotensin I converting enzyme (kininase II) and angiotensinase. J Clin Invest 59 (1982) 6846

[5] LeE MI, HM TodD: Plasma catecholamines and angiotensin-converting enzyme activity in hypertensive subjects with positive rollover tests. Obstet Gynecol 63 (1984) 511

[6] Lieberman J, A SaStre: Serum angiotensin-converting exzyme: Elevations in Diabetes mellitus. Ann Intern Med 93 (1980) 825

[7] OAts JN, FE Pipkin, EM Symonds, DJ Craven: A prospective study of plasma angiotensin-converting enzyme in normotensive primigravidae and their infants. Br J Obstet Gynaecol 88 (1981) 1204

[8] Parente JV, JG Franco, LJ Greene, RS MeirelLES, AR MARTINZE: Angiotensin-converting enzyme: Serum levels during normal pregnancy. Am J Obstet Gynecol 135 (1979) 586

[9] Rasmussen AB, EB Pedersen, FK Romer, D JohanNeSEN, S Kristensen, JG LAURITSEN, M WOHLERT: The influence of normotensive pregnancy and pre-eclampsia on angiotensin-converting enzyme. Acta Obstet Gynecol Scand 62 (1983) 341

[10] Smallridge RC, J Rogers, PS Verma: Serum angiotensin-converting enzyme: Alterations in hyperthyroidism, hypothyroidism, and subacute thyroiditis. JAMA 250 (1983) 2489

[11] WhITE P: Pregnancy complicating diabetes. Am J Med 7 (1949) 609

Received April 25, 1986. Revised August 4, 1986. Accepted August 25, 1986.

Michael J. Gast, M.D., Ph. D.

Department of Obstetrics and Gynecology Washington University School of Medicine 4911 Barnes Hospital Plaza

St. Louis, Missouri 63110, U.S. A. 